\title{
Pengaruh Lingkungan dan Motivasi Belajar Terhadap Prestasi Belajar
}

\author{
Sufi Alawiyah ${ }^{* 1}$, Syukri Ghozali ${ }^{2}$, Suwarsito ${ }^{3}$ \\ 1, 2, 3 Universitas Bina Sarana Informatika \\ *sufi.sfy@bsi.ac.id
}

\begin{abstract}
Abstrak
Penelitian ini ditujukan untuk mengetahui pengaruh lingkungan terhadap prestasi belajar bahasa Inggris dan pengaruh motivasi belajar terhadap prestasi belajar bahasa Inggris. Selanjutnya untuk mengetahui pengaruh lingkungan dan motivasi belajar secara bersamasama terhadap prestasi belajar bahasa Inggris. Penelitian ini dilaksanakan di SMK Ganesha pada bulan Januari-April 2019. Hasil penelitian menunjukkan: 1.) Terdapat pengaruh yang signifikan lingkungan dan motivasi belajar secara bersama-sama terhadap prestasi belajar bahasa Inggris siswa di SMK Ganesha, dibuktikan dengan nilai Sig $=0,000<0,05$. 2.) Terdapat pengaruh yang signifikan lingkungan terhadap prestasi belajar bahasa Inggris, dibuktikan dengan nilai Sig $=0,000<0,05$. 3.) Terdapat pengaruh yang signifikan motivasi belajar terhadap prestasi belajar bahasa Inggris, dibuktikan dengan nilai Sig $=0,004<$ 0,05 . Lingkungan dan motivasi belajar berpengaruh signifikan terhadap prestasi belajar.
\end{abstract}

Kata Kunci: lingkungan, motivasi belajar, prestasi belajar

\section{Pendahuluan}

Dalam kehidupan seperti saat ini, pendidikan memiliki peran yang amat penting untuk wahana untuk meningkatkan kualitas sumber daya manusia. Maju mundurnya suatu bangsa dipengaruhi dan berkaitan dengan keberhasilan pendidikan bangsanya. Sekolah sebagai lembaga pendidikan formal berperan membantu mendidik siswa. maka sekolah bertugas mendidik dan mengajar serta memperbaiki dan memperhalus tingkah laku anak didik yang dibawa dari keluarganya.

Jelasnya bisa dikatakan bahwa sebagian besar pembentukan kecerdasan (pengertian), sikap dan minat sebagai bagian dari pembentukan kepribadian, dilaksanakan oleh sekolah. Kenyataan ini menunjukkan, betapa penting dan besar pengaruh dari sekolah. Di samping bertugas untuk mengembangkan pribadi anak didik secara menyeluruh, fungsi sekolah yang lebih penting sebenarnya adalah menyampaikan pengetahuan dan melaksanakan pendidikan kecerdasan. Fungsi sekolah dalam pendidikan intelektual dapat disamakan dengan fungsi keluarga dalam pendidikan moral.

Masalah yang sering dihadapi sekolah sebagai penyelenggara pendidikan khususnya dalam kegiatan pembelajaran di sekolah adalah rendahnya prestasi belajar siswa. Prestasi adalah hasil yang telah dicapai seseorang dalam melakukan kegiatan. Gagne (1985) menyatakan bahwa Prestasi Belajar dibedakan menjadi lima aspek, yaitu kemampuan intelektual, strategi kognitif, informasi verbal, sikap dan keterampilan. Menurut Bloom dalam Suharsimi Arikunto (1990) bahwa hasil belajar dibedakan menjadi tiga aspek yaitu kognitif, afektif dan psikomotorik. Dalam pendidikan di sekolah, Prestasi belajar adalah tingkat keberhasilan siswa dalam menguasai materi pelajaran yang diwujudkan dengan nilai atau angka. 
Berdasarkan hasil observasi sebelumnya, didapatkan bahwa prestasi belajar bahasa Inggris siswa di SMK Ganesha mengalami penurunan dibandingkan tahun sebelumnya. Motivasi belajar serta lingkungan belajar diduga menjadi faktor yang mempengaruhi prestasi belajar siswa di sekolah.

Hasbullah (2009) mendefinisikan lingkungan belajar adalah sekitar yang dengan sengaja digunakan sebagai alat dalam proses pendidikan (pakaian, keadaan rumah, alat permainan, buku-buku, alat peraga dan lain-lain). Menurut Sardiman (2012), motivasi dapat berfungsi sebagai pendorong usaha dan pencapaian prestasi. Jadi dapat dikatakan bahwa apabila seorang siswa mempunyai motivasi dalam belajar maka prestasi belajar siswa tersebut diharapkan bisa meningkat.

Dalam pembelajaran motivasi tidak begitu saja muncul. Diperlukan teknik-teknik untuk memunculkan motivasi dalam pembelajaran. Menurut Hamzah B. Uno (2012), beberapa teknik motivasi yang dapat dilakukan dalam pembelajaran seperti pemberian motivasi belajara secara verbal, dan menggunakan nilai ulangan sebagai pemacu keberhasilan.

\section{Metode Penelitian}

Jenis penelitian yang digunakan dalam penelitian ini adalah explanatory research atau penelitian penjelasan dengan pendekatan kuantitatif. Jumlah sampel yang digunakan dalam penelitian ini sebanyak 60 responden yang merupakan pelajar di SMK Ganesha Depok. Teknik pengambilan sampel mengggunakan teknik random sampling yaitu sampel diambil secara acak.

\section{Hasil Penelitian}

\section{Uji Normalitas Data}

Tabel 1. Uji Normalitas Data

One-Sample Kolmogoroy-Smirnov Test

\begin{tabular}{ll|r|r|r}
\hline & & \multicolumn{1}{c|}{$\begin{array}{l}\text { PRESTASI } \\
\text { BELAJAR }\end{array}$} & $\begin{array}{r}\text { MOTIVASI } \\
\text { BELAJAR }\end{array}$ & LINGKUNGAN \\
\hline $\mathrm{N}$ & & 60 & 60 & 60 \\
Normal Parametersa.b & Mean & 74.73 & 47.95 & 54.48 \\
& Std. Deviation & 3.231 & 9.741 & 11.419 \\
Most Extreme Differences & Absolute & .167 & .117 & .085 \\
& Positive & .167 & .086 & .048 \\
Kolmogorox-Smirnov Z & Negative & -.133 & -.117 & -.085 \\
Asymp. Sig. (2-tailed) & & 1.294 & .904 & .670 \\
\hline
\end{tabular}

a. Test distribution is Normal.

b. Calculated from data.

Tabel di atas menunjukkan bahwa uji hipotesis yang menyatakan distribusi data pada analisis regresi ini mengikuti distribusi normal. Hal ini ditunjukkan dengan semua nilai Asymp. Sig $>0,05$. Hal ini berarti semua data berdistribusi normal

\section{Uji Multikolinearitas}

Uji multikolinieritas bertujuan untuk menguji apakah model regresi ditemukan adanya korelasi yang sempurna antarvariabel bebas (independent). Model regresi yang baik seharusnya tidak terjadi korelasi yang sempurna diantara variabel bebas. Salah satu cara untuk untuk mendeteksi adanya multikolinieritas adalah dengan melihat tolerance atau varian inflation factor (VIF).Apabila tolerance $<0,1$ atau nilai VIF $>10$ maka terjadi multikolinearitas. 
Tabel 2. Uji Multikolinearitas

\begin{tabular}{|c|c|c|c|}
\hline \multicolumn{4}{|c|}{ Coefficients $^{\mathrm{a}}$} \\
\hline \multirow{2}{*}{\multicolumn{2}{|c|}{ Model }} & \multicolumn{2}{|c|}{ Collinearity Statistics } \\
\hline & & Tolerance & VIF \\
\hline \multirow{3}{*}{1} & (Constant) & & \\
\hline & Lingkungan belajar & 739 & 1.353 \\
\hline & Motivasi belajar & 739 & 1.353 \\
\hline
\end{tabular}

Hasil uji multikolininearitas pada tabel di atas diketahui bahwa hasil Tolerance 0,739>0,1 atau varian inflation factor (VIF) 1,353 < 10. Sehingga dapat dinyatakan bahwa tidak ada multikolinearitas antara lingkungan dan motivasi belajar pada analisis regresi ganda ini.

\section{Pembahasan}

Tabel 3. Hasil Perhitungan Pengujian Koefisien Korelasi Ganda

$$
\text { Variabel } X_{1} \text { dan } X_{2} \text { terhadap } Y
$$

\begin{tabular}{c|r|r|r|r}
\multicolumn{5}{c|}{ Model Summary } \\
\hline Model & R & R Square & $\begin{array}{c}\text { Adjusted R } \\
\text { Square }\end{array}$ & $\begin{array}{c}\text { Std. Error of the } \\
\text { Estimate }\end{array}$ \\
\hline 1 & $.712^{\mathrm{a}}$ & .507 & .490 & 2.307 \\
\hline
\end{tabular}

a. Predictors: (Constant), MOTIVASI BELAJAR, LINGKUNGAN

b. Dependent Variable: PRESTASI BELAJAR

Tabel 4. Hasil Perhitungan Pengujian Signifikansi Koefisien Regresi

Variabel $X_{1}$ dan $X_{2}$ terhadap $Y$

\begin{tabular}{|c|c|c|c|c|c|c|}
\hline \multicolumn{7}{|c|}{ ANOVA $^{\mathrm{a}}$} \\
\hline Model & & Sum of Squares & $\mathrm{df}$ & Mean Square & $\mathrm{F}$ & Sig. \\
\hline & Regression & 312.278 & 2 & 156.139 & 29.329 & $.000^{b}$ \\
\hline 1 & Residual & 303.455 & 57 & 5.324 & & \\
\hline & Total & 615.733 & 59 & & & \\
\hline
\end{tabular}

a. Dependent Variable: PRESTASI BELAJAR

b. Predictors: (Constant), MOTIVASI BELAJAR, LINGKUNGAN

Tabel 5. Hasil Perhitungan Persamaan Regresi Ganda Variabel $X_{1}$ dan $X_{2}$ terhadap $Y$

\begin{tabular}{|c|c|c|c|c|c|c|}
\hline \multicolumn{7}{|c|}{ Coefficients ${ }^{\mathrm{a}}$} \\
\hline \multirow[t]{2}{*}{ Mode } & & \multicolumn{2}{|c|}{ Unstandardized Coefficients } & \multirow{2}{*}{$\begin{array}{l}\text { Standardized } \\
\text { Coefficients } \\
\text { Beta }\end{array}$} & \multirow[t]{2}{*}{$t$} & \multirow[t]{2}{*}{ Sig. } \\
\hline & & B & Std. Error & & & \\
\hline \multirow{3}{*}{1} & (Constant) & 62.027 & 1.702 & & 36.443 & .000 \\
\hline & LINGKUNGAN & .138 & .031 & .489 & 4.522 & .000 \\
\hline & MOTIVASI BELAJAR & .108 & .036 & .325 & 3.004 & .004 \\
\hline
\end{tabular}

\section{Pengaruh Lingkungan (X1) dan Motivasi Belajar (X2) Secara Bersama-Sama Terhadap} Prestasi Belajar Bahasa Inggris (Y)

Hipotesis yang diuji:

$$
\begin{aligned}
& H_{0}: \beta_{y 1}=\beta_{y 2}=0 \\
& H_{1}: \beta_{y 1} \neq 0, \text { atau } \beta_{y 2} \neq 0
\end{aligned}
$$


Artinya:

$\mathrm{H}_{0}$ : tidak terdapat pengaruh lingkungan dan motivasi belajar secara bersama-sama terhadap prestasi belajar bahasa Inggris

$\mathrm{H}_{1}$ : terdapat pengaruh lingkungan dan motivasi belajar secara bersama-sama terhadap prestasi belajar bahasa Inggris

Dari table 5. dapat dinyatakan bahwa terdapat pengaruh yang signifikan lingkungan dan motivasi secara bersama-sama terhadap prestasi belajar bahasa Inggris. Hal ini dibuktikan dengan perolehan nilai Fo $=29.329$ dan Sig. 0,000 $<0,05$.

Sementara itu, persamaan garis regresi ganda dapat dinyatakan dengan $\hat{Y}=62.027+0,138$ $\mathrm{X} 1+0,108 \mathrm{X} 2$. Hal ini memiliki pengertian bahwa kenaikan satu skor variable lingkungan dan motivasi belajar memberikan kontribusi sebesar 0,138 oleh X1 dan 0,108 oleh X2 terhadap variable prestasi belajar bahasa Inggris. Dari tabel 5 juga dapat menjelaskan bahwa secara bersama-sama variable lingkungan dan motivasi belajar memberikan kontribusi sebesar 50.7 $\%$ terhadap variable prestasi belajar bahasa Inggris.

\section{Pengaruh Lingkungan $\left(X_{1}\right)$ Terhadap Prestasi Belajar Bahasa Inggris(Y)}

Hipotesis yang diuji:

$$
\begin{aligned}
& H_{0}: \beta_{y 1}=0 \\
& H_{1}: \beta_{y 1} \neq 0
\end{aligned}
$$

Artinya:

$\mathrm{H}_{0}$ : tidak terdapat pengaruh lingkungan terhadap prestasi belajar bahasa Inggris

$\mathrm{H}_{1}$ : terdapat pengaruh lingkungan terhadap prestasi belajar bahasa Inggris

Dari tabel 5. dapat dinyatakan bahwa terdapat pengaruh yang signifikan lingkungan terhadap prestasi belajar bahasa Inggris. Hal ini dibuktikan dengan perolehan nilai Sig. $0,000<$ 0,05 .

Adapun kontribusi variabel lingkungan terhadap Prestasi belajar bahasa Inggris dapat dinyatakan dengan rumus:

$$
\begin{aligned}
& \mathrm{KD}=\text { Nilai }{ }^{\beta_{x 1 y}} \times \text { Nilai Korelasi Pasialnya }\left({ }^{r_{x 1 y}}\right) \times 100 \% \\
& \mathrm{KD}=0,655 \times 0,489 \times 100 \%=32.03 \%
\end{aligned}
$$

Dari hasil perhitungan di atas dapat dinyatakan bahwa kontribusi lingkungan dalam meningkatkan prestasi belajar bahasa Inggrissebesar $32.03 \%$

\section{Pengaruh Motivasi (X2) Terhadap Prestasi Belajar Bahasa Inggris(Y)}

Hipotesis yang diuji:

$$
\begin{aligned}
& H_{0}: \beta_{y 1}=0 \\
& H_{1}: \beta_{y 1} \neq 0
\end{aligned}
$$

Artinya:

$\mathrm{H}_{0}$ : tidak terdapat pengaruh motivasi terhadap prestasi belajar bahasa Inggris

$\mathrm{H}_{1}$ : terdapat pengaruh motivasi terhadap prestasi belajar bahasa Inggris 
Dari tabel 5. dapat dinyatakan bahwa terdapat pengaruh yang signifikan lingkungan terhadap prestasi belajar bahasa Inggris. Hal ini dibuktikan dengan perolehan Sig. 0,004 < 0,05 .

Adapun kontribusi variabel lingkungan terhadap prestasi belajar bahasa Inggris dapat dinyatakan dengan rumus:

$$
\begin{aligned}
& \mathrm{KD}=\text { Nilai }{ }^{\beta_{x 2 y}} \times \text { Nilai Korelasi Pasialnya }\left({ }^{r_{x 2 y}}\right) \times 100 \% \\
& \mathrm{KD}=0,575 \times 0,325 \times 100 \%=18,67 \%
\end{aligned}
$$

Dari hasil perhitungan di atas dapat dinyatakan bahwa kontribusi lingkungan dalam meningkatkan prestasi belajar bahasa Inggris sebesar $18.67 \%$.

\section{Kesimpulan}

Dari hasil analisa diatas, dapat disimpulkan bahwa lingkungan belajar dan motivasi belajar secara simultan berpengaruh signifikan terhadap prestasi belajar siswa. Lingkugan belajar berpengaruh signifikan terhadap prestasi belajar siswa. Motivasi belajar berpengaruh signifikan terhadap prestasi belajar siswa.

Hasil penelitian membuktikan bahwa lingkungan belajar dan motivasi belajar berpengaruh signifikan terhadap prestasi belajar. Dengan hasil penelitian ini maka disarankan agar orang tua siswa diharapkan mampu menciptakan lingkungan belajar di rumah yang mendukung anak dalam belajar. Sekolah juga diharapkan mampu memberikan suasa belajar yang kondusif yang mendukung kegiatan belajar mengajar menjadi lebih baik. Bagi siswa, hendaknya siswa selalu meningkatkan motivasi dan disiplin dalam belajar antara lain dengan keinginan untuk terus maju serta belajar rutin setiap hari.

\section{Referensi}

Sardiman, A. M. (2012). Interaksi dan Motivasi Belajar Mengajar. Jakarta: Rajawali Pers. Arikunto, S. (1990). Dasar-Dasar Evaluasi Pendidikan. Jakarta: Bumi Aksara Gagne, R. (1985). The Condition of Learning Theory of Instruction. New York: Rinehart. Hasbullah. (2009). Dasar - Dasar Ilmu Pendidikan. Jakarta: Raja Grafindo Persada. Uno, B. H. (2012). Teori Motivasi \& Pengukurannya. Jakarta: Bumi Aksara. 